\title{
The Impact of labor Turnover on The Service Quality of Hotels
}

\author{
M.SALEH ${ }^{1}$, H.KABALAN ${ }^{2}$ \\ 1SYRIAN VIRTUAL UNIVERSITY, Faculty of Management Sciences, motasemsal9177@gmail.com \\ ${ }^{2}$ University of Damascus, Faculty of Economic, Department of Business Administration, \\ hkabalan_b@hotmail.com
}

Abstract. This study aimed to know the dimensions of labor turnover (low morale, poor employees training, payment, job satisfaction) and study the effect of these dimensions on the quality of service in hotels. The results of multiple regression show that there is an effect of dimensions labor turnover on quality of service. Correlation between labor turnover and tangibility was the strongest and there is a moderate relationship between labor turnover and each of responsibility, reliability, assurance, and empathy.

Keywords: labor turnover, service quality, low morale, poor employees training, payment, job satisfaction

\section{Introduction}

For all organizations, turnover intention of employees has become one of the major challenges. To develop the understanding of multifaceted phenomena, researches have formulated different models of employee turnover across the world. This is somewhat due to multiplicity in the samples which are used for the study. Economical, psychological and organizational consequences are symptomatic of the complexity of employee's turnover (Ahmed, et al., 2016).

When an employee leaves the organization, this may have a variety of effects that not only impact on organization but also on employee itself and society also. Although enough literature on employee turnover is available but still there is not universally agreed framework for why employees leave (Curran, 2012).

However, the issue of employee turnover, which the is described as the unplanned loss of workers who voluntarily leave despite their employer's preference to keep them, exists in most organization throughout the word (Memon, et al., 2014).

The concept of labor turnover:

Turnover intention of labor is defined as an employee's personal estimated probability that he or she has a deliberate intent to leaving the organization permanently in near future (Long \& Thean, 2011). According to (Qureshi, et al., 2013) it typically refers to separation of an employee from the firm Types of Employee Turnover: 
- Voluntary turnover: when employees leave an organization at their own it is referred to as voluntary turnover (Noe, et al., 2006). According to (Manu Rita, et al., 2004)it can be affected by a lack of job satisfaction, job stress and as well as alternative opportunities.

- Involuntary turnover: (Mathis \& Jackson, 2004)defines it as "an instance of involuntary turnover or a discharge" that reflects an employer's decision to terminate the employment relationship. Involuntary turnover includes retirement, death and dismissal (Allen, et al., 2004).

Causes of employee turnover:

There are many reasons that make an employee want to quit:

- Low morale: morale in high-turnover firms is usually weak. Company culture is that the shared norms and value of a group of workers who work along. Motivating your workers to share the vision of your business and perform at high levels is tough once colleagues and colleagues are vanishing all around them. Workplace relationships are key to an employee's satisfaction with work (Thomas, 2015).

- Poor employees training: training is a method used to increase job related employee knowledge. Employees beginning a new job need to be introduced to the job, its duties, and the expectations that will be placed upon them. This training should be only the beginning process to mold the employee into the corporate culture and ideals (Hammerberg, 2002).

- Payment: Paying the employee is one of the most important things to ensure that an organization keeps working. Payment is used to refer to any type of reward or compensation offered to a staff for having worked at the organization or for having successfully achieved a task (Brown, 2003).

- Job satisfaction: It is defined as the difference between the volume of some respected consequences a person obtains and the amount of the outcome the person thinks he or she should obtain. Job satisfaction is the extent to which individuals like their jobs. It is widely believed among HR professionals and scholars that job satisfaction leads to employee retention and prevents labour turnover (Moushmi \& Chintamanee, 2018).

Service Quality:

Service is work or experience offered by one party to the opposite party. Although in this process be closely with the physical product. But this act is necessarily intangible and usually does not result in ownership any of the factors of production (Poor, et al., 2013).

Service quality is the gap between what the customers want and what they actually get or perceive they are getting. Consequently, many companies would attempt to offer a high service quality in order to retain their customers. It has been empirically proved that high service quality motivates positive customer behavioral intention to repurchase, and in turn, promotes customer retention. There are five dimensions used in measuring customer service quality. The dimensions included in this model are tangibles, reliability, responsiveness, empathy and assurance. The tangible includes the physical appearance of the facilities, equipment, personnel, and materials used to communicate with customers. Measuring element of responsibility and reliability are speed, willingness to respond, accuracy and dependability. The dimension of assurance and empathy may be measured using elements of knowledge, trained professional, communications and caring (Sam \& Dhanya, 2012). 
The importance of quality service:

In order to achieve competitive advantage, it is most important to focus on service quality because customers are more conscious about quality so it's important to deliver higher service quality better than its competitors. Service quality is an important factor of customer satisfaction as well as word-ofmouth communication (Rehaman \& Husnain, 2018).

\section{Problem and Objectives of the Study}

Work turnover is one of the important problems facing contemporary organizations, which incurs huge and significant costs that are reflected in the outcome on the level of their effectiveness and efficiency in the performance of work. The organizations worked to employ various means to get rid of this problem and that accompanied the progress made in the tourism activity.

The study aims to identify the dimensions of the speed of rotation of the labour force, including:

- Decreased morale of hotel workers

- The inability of the human resources department in the tourism sector to change persons suitable for work

- Low wages for workers

- Lack of interest in training employees

And its relationship to the dimensions of quality of service and work to suggest appropriate solutions to it.

\section{Hypotheses of the Study}

H1 There is a statistically significant effect of low morale on the service quality of hotels.

H2 There is a statistically significant effect of poor employees training on the service quality of hotels.

H3 There is a statistically significant effect of payment on the service quality of hotels.

H4 There is a statistically significant effect of the job satisfaction on the service quality of hotels.

\section{Methodology}

The descriptive analytical approach was followed, including data collection by means of the questionnaire, to reach the objectives of the study and to develop appropriate recommendations. The descriptive approach included calculation of iterations, percentages, arithmetic mean and standard deviations. Relationships between the variables were revealed and hypothesis validity was tested using SPSS

The study style of the office has been followed through books and scientific periodicals in building the theoretical framework for research

The questionnaire was designed to study the relationship between the speed of rotation of the hand and the quality of hotel services in a manner commensurate with the hypotheses set, after reviewing the 
previous studies related to the topics of labor turnover and the quality of hotel services and it was used in the formulation of questionnaire terms where

The questionnaire was designed according to the five-digit scale set by the scientist (Rensis Likert) and the study tool was divided into three parts:

- The first part: the demographic variables (gender - age - educational qualification - years of experience)

- The second part: It is related to the dimensions of the labor rotation speed and consists of 12 questions

- The third part: It is related to the dimensions of the quality of hotel services, and it consists of 15 questions.

As for the study community, a group of hotels operating in Latakia (Syria) Governorate were chosen, namely (Afamia - Blue Beach - Golden Beach- Lamira- Zenobia - Riviera). The number of employees working in these hotels reached 1200 employees. It includes all the employees in these hotels and from different job levels as for the study sample, it is a random sample of workers in these hotels, where the questionnaire was distributed to 110 people, and 90 responses were valid for the purposes of statistical analysis the recovery rate is about $81 \%$.

\section{Results and Discussion}

\subsection{Reliability Test:}

\begin{tabular}{|l|l|l|}
\hline Variable & No. Of Items & Cronbach's Alpha \\
\hline Labour Turnover & 12 & .810 \\
\hline Service Quality & 15 & .902 \\
\hline
\end{tabular}

Table 1. Cronbach's Alpha test

Cronbach's Alpha uses as a reliability testing tool. In table 1 every value of each variable is above 0.7 , it means that these variables have high and good reliability.

\subsection{Correlation analysis of labour turnover and service quality of hotels}

\begin{tabular}{|l|l|l|l|l|l|l|}
\hline Correlations & \multicolumn{7}{l|}{} & Tssurance & Tangibility & Empathy \\
\hline & $\begin{array}{l}\text { Labour } \\
\text { turnover }\end{array}$ & $\begin{array}{l}\text { response } \\
\text { speed }\end{array}$ & Reliability & As & & \\
\hline \multirow{2}{*}{$\begin{array}{l}\text { Labour } \\
\text { turnover }\end{array}$} & $1^{* *}$ & $.591^{* *}$ & $.635^{* *}$ & $.647^{* *}$ & $.705^{* *}$ & $.654^{* *}$ \\
\cline { 2 - 7 } & 90 & .000 & .000 & .000 & .000 & .000 \\
\cline { 2 - 7 } & 90 & 90 & 90 & 90 & 90 \\
\hline \multirow{2}{*}{$\begin{array}{l}\text { response } \\
\text { speed }\end{array}$} & $.591^{* *}$ & $1^{* *}$ & $.621^{* *}$ & $.639^{* *}$ & $.621^{* *}$ & $.639^{* *}$ \\
\cline { 2 - 7 } & .000 & & .000 & .000 & .000 & .000 \\
\cline { 2 - 7 } & 90 & 90 & 90 & 90 & 90 & 90 \\
\hline \multirow{2}{*}{ Reliability } & $.635^{* *}$ & $.621^{* *}$ & $1^{* *}$ & $.662^{* *}$ & $.496^{* *}$ & $.662^{* *}$ \\
\cline { 2 - 7 } & .000 & .000 & & .000 & .000 & .000 \\
\hline
\end{tabular}




\begin{tabular}{|l|l|l|l|l|l|l|}
\hline & 90 & 90 & 90 & 90 & 90 & 90 \\
\hline \multirow{5}{*}{ Assurance } & $.647^{* *}$ & $.639^{* *}$ & $.662^{* *}$ & $1^{* *}$ & $.662^{* *}$ & $.640^{* *}$ \\
\cline { 2 - 7 } & .000 & .000 & .000 & & .000 & .000 \\
\cline { 2 - 7 } & 90 & 90 & 90 & 90 & 90 & 90 \\
\hline \multirow{5}{*}{ Tangibility } & $.705^{* *}$ & $.621^{* *}$ & $.496^{* *}$ & $.662^{* *}$ & $1^{* *}$ & $.662^{* *}$ \\
\cline { 2 - 7 } & .000 & .000 & .000 & .000 & & .000 \\
\cline { 2 - 7 } & 90 & 90 & 90 & 90 & 90 & 90 \\
\hline \multirow{5}{*}{ Empathy } & $.654^{* *}$ & $.639^{* *}$ & $.662^{* *}$ & $.640^{* *}$ & $.662^{* *}$ & $1^{* *}$ \\
\cline { 2 - 7 } & .000 & .000 & .000 & .000 & .000 & \\
\cline { 2 - 7 } & 90 & 90 & 90 & 90 & 90 & 90 \\
\hline \multirow{2}{*}{ Correlation is significant at the 0.01 level (2-tailed) } & & & \\
\hline
\end{tabular}

Table 2. Correlation analysis

The relationship among all the variables was found by suing Pearson's correlation coefficient. The correlation value $r=0.591$ shows that there is a moderate relationship between labour turnover and response speed and the p-value $<0.01$ shows that the relationship is significant. For labour turnover and reliability $r=0.635$ which shows that there is a moderate correlation between these two variables and the $p$ - value $<0.01$ shows a relationship is significant. The value $r=0.647$ shows a moderate relationship between labour turnover and assurance, also $p$-value $<0.01$ shows that the relationship is significant. For labour turnover and tangibility, the $r=0.705$ shows a strong correlation between the two variables, and the $p$-value $<0.01$ shows the relationship is significant. The $r=0.654$ for labour turnover and empathy shows that these two variables are moderately correlated, and the p-value shows $<0.01$ that the relationship is significant.

\subsection{Regression analysis of labour turnover and service quality of hotels}

\begin{tabular}{|l|l|l|l|l|}
\hline Model & R & R Square & $\begin{array}{l}\text { Adjusted R } \\
\text { Square }\end{array}$ & $\begin{array}{l}\text { Std. Error of } \\
\text { the Estimate }\end{array}$ \\
\hline 1 & $.964^{\mathrm{a}}$ & .929 & .926 & .14741 \\
\hline
\end{tabular}

Table 3. The value of the regression coefficient and the determination

\begin{tabular}{|l|l|l|l|l|l|}
\hline Model & $\begin{array}{l}\text { Sum of } \\
\text { Squares }\end{array}$ & Df & Mean Square & F & Sig. \\
\hline Regression & 24.266 & 4 & 6.067 & 279.169 & $.000^{\mathrm{b}}$ \\
\hline Residual & 1.847 & 85 & .022 & & \\
\hline Total & 26.114 & 89 & & & \\
\hline
\end{tabular}

Table 4. Anova test

Dependent Variable: service quality

Predictors: (Constant): low morale, poor employees training, payment, job satisfaction

The linear model was used to determine the relationship between dependent and independent variables. The value of adjusted $R$ square is 0.926 which shows that there is $92.6 \%$ variance in service quality of hotels can be explained by dimensions of labour turnover. The $7.4 \%$ variation in service quality of hotels is due to some other factors. 
The Anova table gives a $\mathrm{p}$ - value $=.000<0.05$ which shows that the fitted regression model is appropriate.

\begin{tabular}{|c|c|c|c|c|c|c|}
\hline \multicolumn{7}{|c|}{ Coefficients $^{a}$} \\
\hline \multirow{2}{*}{\multicolumn{2}{|c|}{ Model }} & \multicolumn{2}{|c|}{$\begin{array}{l}\text { Unstandardized } \\
\text { Coefficients }\end{array}$} & \multirow{2}{*}{$\begin{array}{l}\text { Standardized } \\
\text { Coefficients } \\
\text { Beta }\end{array}$} & \multirow[t]{2}{*}{$\mathrm{T}$} & \multirow[t]{2}{*}{ Sig. } \\
\hline & & B & Std. Error & & & \\
\hline \multirow{5}{*}{1} & (Constant) & .198 & .115 & & 1.722 & .089 \\
\hline & Poor morale & .221 & .027 & .325 & 8.058 & .000 \\
\hline & $\begin{array}{ll}\text { Low } & \text { employees } \\
\text { training } & \end{array}$ & .444 & .032 & .550 & 13.784 & .000 \\
\hline & Payment & .105 & .039 & .150 & 2.687 & .009 \\
\hline & Job satisfaction & .167 & .040 & .232 & 4.201 & .000 \\
\hline
\end{tabular}

Table 5. Regression Analysis

From table 5 the independent variable poor morale has $(B=0.221$, sig $=.000)$ which means that each single unit change in poor morale brought 0.221 unit change in service quality of hotels. The second independent variable low employees training has $(\mathrm{B}=0.444$, sig $=.000)$ which means that each single unit change in low employees training brought 0.444 unit change in service quality of hotels. According to the third independent variable payment, it has $(B=0.105$, sig $=.009)$ which means that ever single unit change in payment brought 0.105 -unit change in service quality of hotels. The independent variable job satisfaction $(B=0.167$, sig $=.000)$ caused 0.167 -unit change in service quality of hotels by a single unit change.

\section{Conclusion}

Based on the results of the study, we recommend the following:

Working to improve the relationship between employees with each other, managing them, and involving them in decisions related to them, identifying work problems and challenges and working to address them. Care must also be taken not to overburden employees in hotels and charge them hours of work beyond their capacity in order to avoid leaving work.

Morale rewards are an essential aspect in preserving employees. Therefore, a good system of promotion must be provided and based on the employee's diligence and experience, not on seniority or on the basis of age.

Paying attention to the salaries of employees working in the hotel sector, where their real incomes must be analysed, not cash, and is it sufficient to ensure a good standard of living for them or not in addition to identifying the salaries and incentives offered by competitors as a way to attract experienced labour.

Adding some advantages to the hotel job, which may attract competencies, just like material benefits such as health and social insurance and end of service benefits.

Determining the training needs of hotel employees to show clear weaknesses in their performance, describing jobs within hotels, and conducting interviews with managers and employees to determine 
what each individual need in addition to periodic evaluation of employees that includes their performance during the previous period.

\section{References}

[1] Ahmed, Z. et al., 2016. Impact of Employee Turnover on Organizational Effectiveness in Tele Communication Sector of Pakistan. IOSR Journal of Business and Management.

[2] Allen, D., Shore , L. M. \& Griffeth, R. W., 2004. The Role of Perceived Organizational Support and Supportive Human Resource Practices in the Turnover Process. Journal of Management.

[3] Brown, 2003. Reward strategies. Journal of personnel management.

[4] C., 2012. Assessing employee turnover in the Language Services Republic of South Africa, s.l.: s.n.

[5] Hammerberg, J., 2002. Reasons given for employee turnover in a full priced department store.

[6] Long, C. \& Thean, L., 2011. Relationship between leadership style, job satisfaction and employees' turnover intention: A literature review. Research journal of business management.

[7] Manu Rita , Negrin \& Shay , . T., 2004. Job search modes and Turnover. Career Development International.

[8] Mathis, J. E. \& Jackson, D. M., 2004. A review and meta-analysis of the antecedents, correlates and consequences of commitment. Psychological Bulletin.

[9] Memon, M., Salleh, R., Bahrom, M. \& Har, 2014. Person-organization fit and turnover intention: the mediating role of employee engagement. Global Business \& Management Research.

[10] Moushmi, R. \& Chintamanee, S., 2018. Cause of Voluntary Labour Turnover: A Case Study of A Five Star Hotel in Mauritius.

[11] Noe, R. A., Hollenbeck, B., Grehart \& Wright, P. M., 2006. Human Resource Management Gaining A Competitive Advantage. 4 ed. New York: McGraw Hill.

[12] Poor, M. H., Poor, M. A. \& Darkhaneh, 2013. The quality of service and its importance in service organizations. Arabian Journal of Business and Management Review (OMAN Chapter),.

[13] Qureshi, M., Iftikhar, M., Abbas, S. \& Hassan, 2013. Relationship between job stress, workload, environment and employees' turnover intentions: What we know, what should we know. World Applied Sciences Journal.

[14] Rehaman, B. \& Husnain, M., 2018. The impact of service quality dimensions on patient satisfaction in the private healthcare industry in Pakistan. J Hosp Med Manage [Internet]. 
[15] Sam, T. \& Dhanya, 2012. Impact of product quality, service quality and contextual experience on customer perceived value and future buying intentions. European journal of business and management, 3(No.3).

[16] Thomas, J., 2015. Study on causes and effects of employee turnover in construction industry. International Journal of Science and Research. 